\title{
PENGARUH SARI KURMA (PHOENIX DACTYLIFERA) TERHADAP PENINGKATAN KADAR HEMOGLOBIN PADA REMAJA PUTRI
}

\author{
Puspita Adriani, Irmayanti, Siti Nurrahmah \\ Akademi Kebidanan Konawe, Jl. DII Panjaitan No. 217 Kel. Tuoy Kab. Konawe Prov. Sulawesi Tenggara, \\ 085211011717 \\ puspitaadriani@yahoo.co.id
}

\begin{abstract}
ABSTRAK
Wanita mempunyai risiko terkena anemia paling tinggi terutama pada remaja putri, hal ini disebabkan karena aktivitas perkuliahan yang padat sehingga banyak membutuhkan energi, namun kebanyakan mahasiswa kebutuhan nutrisinya tidak tercukupi karena seringnya mengkonsumsi makanan siap saji (mie instant dan sebagainya). Selain itu, tidak adanya kesadaran untuk mengkonsumsi tablet tambah darah pada saat menstruasi. Penelitian mengenai suplemen zat besi untuk memenuhi kebutuhan zat besi telah banyak dilakukan, namun herbal belum mendapat perhatian dan hal ini perlu dikembangkan salah satunya adalah sari kurma. Penelitian ini bertujuan untuk mengidentifikasi pengaruh sari kurma (phoenix dactylifera) terhadap peningkatan kadar hemoglobin pada remaja putri. Jenis penelitian menggunakan Quasi Eksperimen dengan rancangan Non Equivalent Control Grup. Teknik sampling secara purposive sampling dan diperoleh 38 responden. Analisa penelitian menggunakan analisa univariat dan bivariat (uji Chi Square). Hasil penelitian menunjukkan sari kurma secara signifikan berpengaruh terhadap peningkatan kadar hemoglobin dengan nilai asympt sig $(0,023)<$ nilai probabilitas $(0,05)$. Kesimpulan penelitian, terdapat peningkatan kadar hemoglobin pada remaja putri yang mengkonsumsi sari kurma dibandingkan yang tidak mengkonsumsi sari kurma.
\end{abstract}

Kata kunci : sari kurma; hemoglobin; remaja putri; anemia

\section{THE EFFECT OF DATE SEED (PHOENIX DACTYLIFERA) TOWARDS THE INCREASE OF HEMOGLOBIN LEVELS IN FEMALE ADOLESCENTS}

\begin{abstract}
Women have the highest risk in getting anemia, especially in adolescents girls, this is due to dense lecture activities that required a lot of energy, but most of the students' nutritional needs are not fulfilled because they often consumed junk food (instant noodles and so on). In addition, there is no awareness to consume iron supplement during menstruation. A number of researches on iron supplements to fulfill iron needs have been done, but the herbs have not received attention and need to be developed, one of the herbs is date juice. This study was aimed to identify the effect of date palm extract (phoenix dactylifera) on increasing hemoglobin levels for female adolescents. This study used Quasi Experiment with Non Equivalent Control Group design. The sampling technique was purposive sampling and obtained 38 respondents. The data analysis used univariate and bivariate analysis (Chi Square test). The results showed that date palm juice had a significant effect on increasing hemoglobin levels with asympt sig value $(0.023)<$ probability value $(0.05)$. The conclusion is that there is an increase in hemoglobin levels in adolescent girls who consume date palm juice compared to those who do not consume date juice.
\end{abstract}

Key words: date palm extract; hemoglobin; female adolescent; anemia 


\section{LATAR BELAKANG}

Wanita mempunyai risiko terkena anemia paling tinggi terutama pada remaja. Hal ini dikarenakan remaja putri mengalami menstruasi setiap bulannya, asupan makanan yang rendah, kebutuhan zat besi meningkat karena proses percepatan pertumbuhan (growth spirit), dan melakukan pembatasan konsumsi makanan sehingga konsentrasi zat besi dalam darah dapat berkurang dan kadar hemoglobin atau sel darah merah menurun yang menyebabkan terjadinya anemia (Kemenkes RI, 2018).

Kekurangan zat besi dapat menurunkan daya tahan tubuh sehingga dapat menyebabkan produktivitas menurun. Asupan zat besi dapat diperoleh melalui makanan bersumber protein hewani seperti hati, ikan dan daging. Namun, tidak semua masyarakat dapat mengkonsumsi makanan tersebut, sehingga diperlukan asupan zat besi tambahan yang diperoleh dari tablet tambah darah (Fe). Program pemberian suplementasi besi yang direkomendasikan oleh World Health Organization (WHO) mulanya hanya kepada ibu hamil, namun seiring berjalannya waktu sasaran program ditambah menjadi balita, anak usia sekolah dan Wanita Usia Subur (WUS) (Kemenkes RI, 2018).

Sesuai dengan Surat Edaran Direktur Jenderal Kesehatan Masyarakat Kementerian Kesehatan Nomor HK.03.03/V/0595/2016 tentang Pemberian Tablet Tambah Darah (Fe) pada remaja putri dan WUS pemberiannya dilakukan melalui UKS/M di Institusi Pendidikan (SMP dan SMA atau yang sederajat) dengan menentukan hari minum tablet tambah darah (Fe) bersama. Dosis yang diberikan adalah satu tablet setiap minggu selama sepanjang tahun.

Pemberian tablet tambah darat (Fe) pada remaja putri bertujuan untuk memenuhi kebutuhan zat besi bagi para remaja putri yang akan menjadi ibu di masa yang akan datang, sebab dengan cukupnya asupan zat besi sejak dini, diharapkan angka kejadian anemia pada ibu hamil, perdarahan saat persalinan, Bayi Berat Lahir Rendah (BBLR) dan balita pendek dapat menurun (Kemenkes RI, 2018).
Hasil Riset Kesehatan Dasar (Riskesdas) tahun 2013, prevalensi anemia pada remaja putri usia 13-18 tahun sebesar $22,7 \%$ dan pada ibu hamil sebesar $37,1 \%$. Sedangkan tahun 2018 prevalensi anemia pada remaja putri usia 15-24 tahun sebesar 27,2\% dan pada ibu hamil sebesar $48,9 \%$ yang artinya terjadi peningkatan (Kemenkes RI, 2019).

Direktorat Jenderal Kesehatan Masyarakat Kementerian Kesehatan Republik Indonesia, menyebutkan bahwa cakupan pemberian tablet tambah darah (Fe) pada remaja putri di Indonesia dalam rentan tiga tahun terakhir mengalami fluktuasi yaitu pada tahun 2017 sebesar 29,51\%, tahun 2018 sebesar 48,52\% dan pada tahun 2019 sebesar 46,56\%. Sedangkan untuk Provinsi Sulawesi Tenggara mengalami peningkatan yang cukup signifikan yaitu pada tahun 2017 sebesar 53,64\%, tahun 2018 sebesar 60,43\% dan pada tahun 2019 sebesar 80,72\% (Kemenkes RI, 2019).

Penelitian yang dilakukan oleh Fatmawati (2018) tentang anemia pada remaja di Akademi Kebidanan Konawe mendapatkan hasil bahwa sebagian besar dari sampel mengalami anemia. Hal ini disebabkan karena aktivitas perkuliahan yang padat sehingga banyak membutuhkan energi, namun kebanyakan mahasiswa kebutuhan nutrisinya tidak tercukupi karena seringnya mengkonsumsi makanan siap saji (mie instant dan sebagainya). Selain itu, tidak adanya kesadaran untuk mengkonsumsi tablet tambah darah (Fe) pada saat menstruasi.

Penelitian lain yang pernah dilakukan oleh Widiastuti dan Rusmini (2019) tentang kepatuhan konsumsi tablet tambah darah pada remaja putri menyebutkan bahwa sebagian besar tidak mengkonsumsi atau menghabiskan tablet tambah darah (Fe) disebabkan karena ada rasa mual, konstipasi, tinja berwarna hitam dan diare, tidak suka dengan bau ataupun rasa dan adanya rasa malas karena merasa tidak perlu.

Penelitian mengenai suplemen zat besi telah banyak dilakukan. Salah satunya berkhasiat untuk mengobati penyakit anemia defisiensi besi, namun efek samping yang ditimbulkan akibat penggunaan suplemen zat 
besi sangat membuat para remaja maupun ibu hamil ketika mengkonsumsinya menjadi tidak nyaman. Khasiat tumbuhan herbal belum mendapat perhatian dan hal ini perlu dikembangkan. Sari kurma merupakan hasil olahan buah kurma yang memiliki kandungan besi sebesar 1,5 mg per buah. Selain itu, kurma juga mengandung protein, serat, glukosa, vitamin, biotin, niasin, dan asam folat. Kurma juga mengandung mineral seperti, kalsium, sodium dan potassium (Isa, 2011).

Hasil penelitian yang dilakukan oleh Mawaddah dan Vopy (2019) menunjukkan bahwa ada hubungan pemberian sari kurma terhadap kadar hemoglobin remaja putri yang mengalami anemia. Penelitian serupa yang dilakukan oleh Pravitasari (2014) menyatakan bahwa ekstrak buah kurma dapat meningkatkan kadar hemoglobin, ekstrak buah kurma (phoenix dactylifera) dapat memiliki sifat mampu mendukung peningkatan sintesis erythropoietin oleh hati untuk merangsang sumsum tulang untuk menghasilkan lebih banyak sel darah merah/haemopoiesis.

Penelitian ini bertujuan untuk mengidentifikasi pengaruh sari kurma (phoenix dactylifera) terhadap peningkatan kadar hemoglobin pada remaja putri.

\section{METODE}

Jenis penelitian menggunakan Eksperimen Semu (Quasi Eksperimen) dengan rancangan Non Equivalent Control Grup. Peneliti menentukan sampel yang terdapat dalam populasi yaitu secara purpossive sampling dan diperoleh sebanyak 38 responden dengan rentang usia 17-24 tahun, tidak sedang berpuasa, tidak sedang menstruasi, tidak sedang menderita penyakit infeksi/kronis, tidak sedang mengkonsumsi obat-obatan termasuk tablet tambah darah dan tidak sedang sakit pada saat proses pengambilan data. Sampel dibagi menjadi 2 kelompok yaitu kelompok intervensi (19 responden) : remaja yang mengkonsumsi sari kurma 30ml/hari/orang atau 1 sendok makan/hari setelah makan pagi dan malam selama 12 hari, sedangkan kelompok kontrol (19 responden) : remaja yang tidak mengkonsumsi sari kurma. Kemudian dilakukan pretest berupa cek $\mathrm{Hb}$ pada kedua kelompok tersebut. Setelah 12 hari dilakukan posttest berupa cek $\mathrm{Hb}$ pada kedua kelompok tersebut. Instrumen yang digunakan dalam penelitian ini adalah hemoglobinometer digital dan lembar observasi. Analisis data menggunakan analisis univariat dan uji chi square (digunakan untuk melihat perbedaan dua kategori dalam skala nominal yaitu kadar hemoglobin meningkat atau tidak meningkat setelah dilakukan intervensi) yang diperoleh dengan menggunakan program SPSS.

\section{HASIL}

Analisa univariat digunakan untuk melihat gambaran distribusi frekuensi variabel penelitian.

Tabel 1. Distribusi Frekuensi Kadar Hemoglobin pada Kelompok Kontrol

\begin{tabular}{ccc}
\hline Kadar $\mathrm{Hb}$ & $\mathrm{n}$ & $\%$ \\
\hline Meningkat & 6 & 31,58 \\
Tidak Meningkat & 13 & 68,42 \\
\hline Jumlah & 19 & 100 \\
\hline
\end{tabular}

Tabel 1 menunjukkan bahwa distribusi frekuensi kadar hemoglobin pada kelompok kontrol terdapat 6 orang $(31,58 \%)$ yang kadar hemoglobinnya meningkat dan terdapat 13 orang $(68,42 \%)$ yang kadar hemoglobinnya tidak meningkat.

Tabel 2. Distribusi Frekuensi Kadar Hemoglobin pada Kelompok Intervensi

\begin{tabular}{ccc}
\hline Kadar $\mathrm{Hb}$ & $\mathrm{n}$ & $\%$ \\
\hline Meningkat & 13 & 68,42 \\
Tidak Meningkat & 6 & 31,58 \\
Jumlah & 19 & 100 \\
\hline
\end{tabular}

Tabel 2 menunjukkan bahwa bahwa distribusi frekuensi kadar hemoglobin pada kelompok intervensi terdapat 13 orang $(68,42 \%)$ yang kadar hemoglobinnya meningkat dan terdapat 6 orang $(31,58 \%)$ yang kadar hemoglobinnya tidak meningkat. 
Analisa bivariat digunakan untuk mengetahui pengaruh variabel independen (sari kurma) terhadap variabel dependen (kadar hemoglobin).

Tabel 3. Hasil Analisis Pengaruh Sari Kurma terhadap Peningkatan Kadar Hemoglobin

\begin{tabular}{ccccccc}
\hline Kadar & \multicolumn{4}{c}{ Sari Kurma } & \multicolumn{2}{c}{ Jumlah } \\
\cline { 2 - 7 } $\mathrm{Hb}$ & \multicolumn{3}{c}{ Kontrol } & \multicolumn{3}{c}{ Intervensi } \\
& $\mathrm{n}$ & $\%$ & $\mathrm{~N}$ & $\%$ & $\mathrm{n}$ & $\%$ \\
Meningkat & 6 & 15,79 & 13 & 34,21 & 19 & 50 \\
$\quad \begin{array}{c}\text { Tidak } \\
\text { Meningkat }\end{array}$ & 13 & 34,21 & 6 & 15,79 & 19 & 50 \\
$\begin{array}{c}\text { Jumlah } \\
\text { Sig }\end{array}$ & 19 & 50 & 19 & 50 & 38 & 100 \\
\hline
\end{tabular}

Tabel 3 menunjukkan bahwa nilai asympt sig $(0,023)<$ nilai probabilitas $(0,05)$. Hal ini menunjukkan bahwa ada perbedaan hemoglobin antara kelompok kontrol dan kelompok intervensi, yang berarti Ha diterima dan $\mathrm{HO}$ ditolak. Sehingga dapat ditarik kesimpulan bahwa sari kurma berpengaruh secara signifikan terhadap peningkatan kadar hemoglobin pada remaja putri.

\section{PEMBAHASAN}

Sari kurma merupakan hasil olahan buah kurma yang memiliki kandungan besi $1,5 \mathrm{mg}$ per buah. Zat besi berperan sebagai bahan baku pembuatan sel darah merah. Selain itu, sari kurma juga mengandung komponen yang mampu meningkatkan penyerapan zat besi atau berperan dalam pembentukan sel darah merah tempat hemoglobin berada diantaranya vitamin, mineral, antioksidan dan lain-lain (Parvin et al, 2015).

Mengkonsumsi sari kurma secara rutin menambah asupan zat besi yang tentunya akan semakin meningkatkan kadar hemoglobin pada remaja. Sari kurma juga berfungsi sebagai pengobatan dan merawat kesehatan tubuh, jadi bagi remaja yang mengalami keluhan dan ketidaknyamanan dari efek samping suplementasi zat besi seperti rasa mual, sulit BAB atau konstipasi, tinja berwarna hitam dan diare dapat mengambil alternatif dengan cara mengkonsumsi sari kurma secara rutin.
Penelitian yang pernah dilakukan oleh Mawaddah dan Vopy (2019) menunjukkan bahwa ada hubungan pemberian sari kurma terhadap kadar hemoglobin remaja putri yang mengalami anemia. Penelitian serupa yang dilakukan oleh Pravitasari (2014) menyatakan bahwa ekstrak buah kurma dapat meningkatkan kadar hemoglobin, ekstrak buah kurma (phoenix dactylifera) dapat memiliki sifat mampu mendukung peningkatan sintesis erythropoietin oleh hati untuk merangsang sumsum tulang untuk menghasilkan lebih banyak sel darah merah/haemopoiesis.

Penyerapan zat besi di dalam tubuh, berkaitan erat dengan lingkungan asam yang membantu penyerapan zat besi, yang terjadi dibagian pertama dan kedua dari usus kecil. Oleh karena itu, penyerapan bisa ditingkatkan dengan pemberian bersama senyawa asam seperti vitamin $\mathrm{C}$ atau asam askorbat. Vitamin $C$ yang terkandung dalam sari kurma dapat meningkatkan penyerapan besi terutama dengan mereduksi besi Ferri menjadi besi Ferro.

Selain dari perannya dalam pengubah Ferri menjadi Ferro sebelum penyerapan usus, vitamin $\mathrm{C}$ juga mengatur homeostasis besi dengan menghambat ekspresi hepcidin (misalnya dalam sel HepG2), menjadikan vitamin $\mathrm{C}$ berpotensi membantu melemahkan defisiensi besi (Imam et al, 2017).

Pembentukan sel darah merah juga dipengaruhi adanya vitamn B12 dan asam folat. Vitamin B12 akan mengaktivasi asam folat. Bentuk aktif asam folat mampu memperbaiki fungsi sel seperti sum-sum tulang (Onuh, 2012). Selain itu kandungan protein, karbohidrat dan lemak yang terdapat pada sari kurma mendukung proses sintesis hemoglobin. Karbohidrat dan lemak membentuk suksinil CoA yang selanjutnya bersama glisin akan membentuk protoporfirin melalui serangkaian proses porifirinogen. Protoporfirin yang terbentuk selanjutnya bersama molekul heme dan protein globin membentuk hemoglobin (Sotolu et al, 2011). 


\section{KESIMPULAN DAN SARAN}

Hasil penelitian dapat disimpulkan bahwa sari kurma berpengaruh secara signifikan terhadap peningkatan kadar hemoglobin pada remaja putri. Anemia rentan terjadi pada remaja putri karena adanya siklus menstruasi setiap bulan, sehingga untuk mencegahnya sari kurma dapat digunakan sebagai salah satu alternatif pilihan bagi remaja putri untuk memenuhi kebutuhan zat besi dengan mengkonsumsinya secara rutin agar hemoglobin dapat meningkat. .

\section{REFERENSI}

Fatmawati, Y. (2018). Hubungan Pengetahuan tentang Asupan Nutrisi dengan Kejadian Anemia pada Mahasiswi Tingkat II di Akademi Kebidanan Konawe. Karya Tulis IImiah. Akademi Kebidanan Konawe

Imam, M et al. (2017). Antioxidants Mediate Both Iron Homeostasis and Oxidative Stress. Nutrients Vol. 9 No. 7, 2017

Kemenkes RI. (2018). Profil Kesehatan Indonesia. Jakarta : Kementerian Kesehatan Republik Indonesia
Kemenkes RI. (2019). Profil Kesehatan Indonesia. Jakarta : Kementerian Kesehatan Republik Indonesia

Mawaddah, S dan Vopy. (2019). Pengaruh Pemberian sari Kurma terhadap Peningkatan Kadar Hemoglobin pada Remaja Putri yang Mengalami Anemia. Media Informasi Vol. 15 No. 2 Tahun 2019

Onuh, S et al. (2012). Haemopoietic Activity and Effect of Crude Fruit Extract of Phoenix Dactylivera on Peripheral Blood Parameters. BioMedSciDierect Publications vol. 3 No. 2, 2012

Pravitasari. (2014). Efek Ekstrak Buah Kurma terhadap Hemoglobin Darah Secara In Vitro pada Tikus Putih Jantan. Surabaya : Fakultas Kedokteran Universitas Airlangga

Isa, N. (2011). Buah Pohon Kurma: Manfaat dan Khasiat Pohon \& Buah Kurma, http://syadiashare.com/manfaat-dan-khasiatpohon-buah-kurma.html.

Sotolu, AO et al. (2011). Nutritional Evaluation of Date Palm (Phoenix dactylivera) Seed and Fruit As Source Of Feeds In Aquaculture. EJEAF Che, 10 (5).

Widiastuti, A dan Rusmini. (2019). Kepatuhan Konsumsi Tablet Tambah Darah pada Remaja Putri. Jurnal Sains Kebidanan Vol. 1 No. 1 November 2019 